\title{
El nacimiento de Alianza Popular como confluencia de proyectos de supervivencia franquista (1974-1976)
}

\author{
Miguel A. Del Río Morillas \\ National Tsing Hua University
}

\section{INTRODUCCIÓN}

La mayoría de la historiografía y estudios sobre Alianza Popular (AP) suelen focalizar sus orígenes, exclusivamente, en la experiencia de GODSA (Gabinete de Orientación y Documentación, S.A.), Reforma Democrática (RD) y Manuel Fraga, sin resaltar la importancia de los restantes componentes de la plataforma (6 asociaciones / partido de origen franquista). ${ }^{2}$ Sin querer quitar mérito al empuje de Fraga y su órbita, es necesario recalcar que el político gallego sería el último en llegar al proyecto neofranquista que sería la plataforma de AP en 1976. El presente artículo pretende analizar uno de los orígenes políticos del principal partido vertebrador de la actual derecha española (el Partido Popular [PP]) como confluencia de proyectos y culturas políticas franquistas de diversa índole (falangista,

${ }^{1}$ Parte del presente artículo está basado en la tesis doctoral del autor, M.A. del Río Morillas: De la extrema derecha neofranquista a la derecha conservadora: los orígenes de Alianza Popular (1973-1979), tesis doctoral, Universitat Autònoma de Barcelona, 2013. Asimismo, forma parte del proyecto " "Taiwan and Spain: A Comparison of TheirTransitionProcessesfromAuthoritarianism to Democracy» financiado por el Ministerio de Asuntos Exteriores (MOFA, por sus siglas en inglés) de la República de China (Taiwan) a través de las becas postdoctorales MOFA Taiwan Fellowship.

${ }^{2}$ Ejemplos representativos que siguen ese relato son los correspondientes a los dos principales estudios existentes sobre AP / PP a nivel estatal, L. López Nieto: Alianza Popular: estructura y evolución de un partido conservador (1976-1982), CIS, Madrid, 1988, y M. Penella: Los orígenes y la evolución del Partido Popular. Una historia de AP (1973-1989), 2 vols., Caja Duero, Salamanca, 2005. Un estado de la cuestión sobre la bibliografía y estudios existentes sobre AP y la problemática de su categorización política pueden consultarse, en M.A. del Río Morillas: «Los orígenes de AP: entre el reformismo institucional y la extrema derecha neofranquista nacional-populista (1976-1979). Un estado de la cuestión», Franquisme E Transició. Revista d'Història i de Cultura, 3 (2015), pp. 301-333. 
tradicionalista, nacional-católica, entre las más destacadas) y no exclusivamente como simple proyecto personalista del reformismo franquista de Manuel Fraga. En este sentido, el artículo parte del proceso de gestación/confluencia que se desarrollaría entre 1974-1975 (especialmente a partir del Estatuto de Asociaciones Políticas impulsado por el gobierno de Arias Navarro), cuando se iniciaron las conversaciones para unificar las fuerzas políticas del 18 de Julio entorno a una macroasociación del Movimiento Nacional que revitalizara las estructuras de encauzamiento político del régimen en el sí de una parte del reformismo franquista más «resistencialista». El proceso finalizaría con la formación de un partido político aglutinador de ese segmento político en octubre de 1976 (AP) en un contexto marcado por la necesidad imperiosa de «salvar» todo lo que significase la obra del 18 de Julio y frenar «el avance del marxismo» en el proceso de reforma del régimen liderado desde julio de 1976 por el segundo gobierno de la monarquía encabezado por Adolfo Suárez tras el fracaso del binomio Arias-Fraga del primer gobierno de la monarquía (diciembre 1975-julio 1976).

Asimismo, partimos de la propuesta interpretativa sobre tres diferentes -aunque complementarios- vectores sobre los cuales creemos se origina AP. Por una parte, como proyecto de confluencia «resistencial» de asociaciones/partidos franquistas con nacimiento al calor del Movimiento Nacional (tal como pretendemos mostrar en el presente artículo). De igual forma, partimos analíticamente de la eclosión de AP como consecuencia de la división del reformismo franquista durante el segundo gobierno de la monarquía entre reformismo «suarista» $\mathrm{y}$ «fraguista», siendo una de sus máximas diferencias el grado de profusión y metodología del mismo "cambio controlado» que se estaba intentando realizar desde las estructuras franquistas cara la democratización del sistema a partir de la promulgación de la octava Ley Fundamental (la Ley para la Reforma Política). En resumen, el segundo vector (el cual no desarrollaremos en el presente artículo por falta de espacio) sería fruto de la división del reformismo franquista a partir del segundo gobierno de la monarquía entre lo que sería Unión de Centro Democrático (UCD) y AP, respectivamente. ${ }^{3}$

Y tercero, partimos de la definición de AP, en sus orígenes (1976-1979), como una experiencia política englobada en la extrema derecha nacional-populista europea (del tipo Movimiento Social Italiano [MSI], el Partido Nacional Demócrata

${ }^{3}$ Diferentes análisis sobre la clase reformista franquista en el proceso de la Transición española pueden seguirse, en A. Soto: ¿Atado y bien atado? Institucionalización y crisis del franquismo, Biblioteca Nueva, Madrid, 2005; C. Palomares: Sobrevivir después de Franco. Evolución y triunfo del reformismo, 19641977, Alianza Editorial, Madrid, 2006; F. Gallego: El mito de la Transición. La crisis del franquismo y los orígenes de la democracia (1973-1977), Crítica, Barcelona, 2008; C. Molinero y P.Ysàs: La anatomía del franquismo. De la supervivencia a la agonía, 1945-1977, Crítica, Barcelona, 2008; M. Rovira Martínez: La Transició franquista. Un exercici d'apropiació de la història, Pòrtic, Barcelona, 2014; I.Sánchez-Cuenca: Atado y mal atado. El suicidio institucional del franquismo y el surgimiento de la democracia, Alianza Editorial, Madrid, 2014. 
de Alemania [NPD, por sus siglas en alemán] o el Frente Nacional [FNa] francés) y no como una mera fuerza política ubicada en la derecha democrática española. La firmeza de no querer renegar del franquismo (aunque sin querer restaurar la etapa más fascista de los años cuarenta y cincuenta -como defendía Fuerza Nueva [FN]-), ni de querer romper con sus legitimidades (AP se niega a la apertura de un proceso constituyente, aunque finalmente, a pesar de la negativa de sus bases, participa cuando es inevitable para no quedar excluido del sistema), muestran los verdaderos límites del proyecto democrático originario de $\mathrm{AP}^{4}$

\section{EL NACIMIENTO DE LA PLATAFORMA NEOFRANQUiSTA AP}

El nacimiento de AP se concretó el 9 de octubre de 1976 después de que las reuniones mantenidas entre Manuel Fraga, Cruz Martínez Esteruelas, Laureano López Rodó, Gonzalo Fernández de la Mora, Thomas de Carranza, Licinio de la Fuente y Federico Silva Muñoz fructificaran en la formación de una federación de partidos-asociaciones, a pesar de que algunas de ellas estaban en proceso de constitución como Democracia Social (DS) liderada por el falangista Licinio de la Fuente, Acción Regional (AR) de López Rodó o la católica colaboracionista de origen franquista, Acción Democrática Española (ADE) de Silva Muñoz (escisión esta última de la también asociación política católica franquista Unión Democrática Española [UDE]). De las siete organizaciones políticas integrantes de la originaria plataforma aliancista, Unión del Pueblo Español (UDPE), Unión Nacional Española (UNE) y Asociación Nacional para el Estudio de Problemas Actuales (ANEPA) habían nacido bajo el estatuto regulador asociativo de 1974 inspirado y controlado por el Consejo Nacional -con la carga ideológica que ello suponía-, siendo las restantes RD, AR, ADE, DS y Unión Social Popular (USP, escisión de ANEPA) las que nacerían a partir del marco regulador asociativo de junio de 1976, supervisado éste último por el Ministerio de la Gobernación ${ }^{5}$ y

\footnotetext{
${ }^{4}$ Sobre la categorización de la inicial AP como una fuerza de extrema derecha neofranquista de corte nacional-populista postfascista, seguimos la senda abierta por el historiador Ferran Gallego (Una patria imaginaria. La extrema derecha española (1973-2005), Síntesis, Madrid, 2006, o «Nostalgia y modernización. La extrema derecha ante la crisis del franquismo y los orígenes de la democracia (1973-1986)», Ayer, 71 (2008), pp. 175-209) y que hemos profundizado, en M.A del Río Morillas: De la extrema derecha..., cit. Otras interpretaciones sobre AP, en este caso fuera de la evolución general de la extrema derecha durante la Transición, pueden seguirse, en J.L. Rodríguez Jiménez: Reaccionarios y golpistas. La extrema derecha en España: del tardofranquismo a la consolidación de la democracia (1967-1982), CIS, Madrid, 1994, y X. Casals: La tentación neofascista en España. La evolución de la extrema derecha española durante la transición, así como sus espejos y referentes europeos, Plaza \& Janés, Barcelona, 1998.

${ }^{5}$ Recordar que el marco regulador asociativo de junio de 1976 fue completado por el Real Decreto 2281/1976 con fecha de 16 septiembre octubre de 1976, aparecido el 1 de octubre en el Boletín Oficial del Estado (BOE), en el que se regulaba el Registro Nacional de Asociaciones Políticas.
} 
del cual nacería formalmente la misma Federación de Alianza Popular (FAP) y el Partido Unido de Alianza Popular (PUAP).

En este sentido, cabe poner de relieve que las siete agrupaciones aliancistas representaban a la mayoría de las culturas políticas ubicadas en el franquismo, a saber: (1) la UDPE, liderada por Cruz Martínez Esteruelas, reunía a los sectores «azules», especialmente los funcionarios de las estructuras del Movimiento Nacional; (2) la UNE, liderada por Gonzalo Fernández de la Mora, de tendencia tradicionalista, aglutinaba a una parte destacada del carlismo franquista; (3) la ADE, liderada por Federico Silva Muñoz, agrupaba a una parte de los sectores católicos colaboracionistas del franquismo; (4) la RD, liderada por Manuel Fraga, aunaba a una parte de las fuerzas procedentes del reformismo azul joseantoniano y de sectores «liberalizantes» del franquismo; (5) la AR, liderada por Laureano López Rodó, de tendencia tecnocrática «regionalista»; (6) la DS, liderada por Licinio de la Fuente, de tendencia «neofalangista evolutiva»; (7) la USP, liderada por Enrique Thomas de Carranza, la cual no se decantaba por ninguna de las culturas políticas del franquismo al intentar presentarse como una plataforma aglutinante de las fuerzas del 18 de Julio. ${ }^{6}$ Legalmente sería inscrita como federación de asociaciones/partido bajo el nombre oficial de Federación de Alianza Popular, ${ }^{7}$ aunque generalmente se la conocía simplemente como Alianza Popular. Asimismo, integraban la inicial FAP: RD, UDPE, AR, USP, DS (todos ellas unificadas en el

\footnotetext{
${ }^{6}$ Un seguimiento sobre los orígenes y desarrollo de las asociaciones/ partido fundadoras de AP, a nivel estatal, puede seguirse, en M. Penella: Los orígenes..., cit., especialmente cap. VI; J. Gil Pecharromán: El Movimiento Nacional (1937-1977), Planeta, Barcelona, 2013, pp. 192 y ss.; M.A. del Río Morillas: De la extrema derecha...cit., pp.72 y ss. Un seguimiento a nivel autonómico, en este caso catalán, en J.B. Culla: La dreta española a Catalunya, 1975-2008, La Campana, Barcelona, 2009, especialmente cap. I. Los casos concretos de UDPE, UNE y AR también pueden seguirse, respetivamente, en M.A. del Río Morillas: «Unión del Pueblo Español (UDPE): los orígenes de la macroasociación azul de Alianza Popular», en M. A. Ruiz Carnicer (ed.): Falange: las cultures políticas del fascismo en la España de Franco (1936-1975)» [CD-ROM], Institución Fernando el Católico, Zaragoza, 2013, pp. 499-511; íd.:«Origen y desarrollo de la Unión Nacional Española (UNE): la experiencia de la extrema derecha neofranquista tradicionalista de Alianza Popular (AP)», en C. Molinero y J. Tébar (Eds.): VIII Encuentro Internacional de Investigadores del Franquismo [CD-ROM], CEFID-UAB/ Fundación Cipriano García de CCOO de Cataluña, Barcelona, 2013; íd:: Acción Regional e López Rodó:“il regionalismo bien entendido" di Alianza Popular (1976-1977)», Nazioni e Regioni. Stdudi e ricerchesullacomunitàimmaginata, 5 (2015), pp. 63-80. Disponible on-line en: http:// www.nazionieregioni.it/wp-content/uploads/NeRe-6_2015_v.3.0.pdf

${ }^{7}$ Registro de Partidos Políticos (RPP), Subdirección General de la Política Interior y Procesos Electorales (SGPIYPE), Ministerio del Interior (MI), carpeta 171, «Certificado de inscripción de la asociación política Federación de Alianza Popular», Madrid, 22 de marzo de 1977.
} 
PUAP tras el primer congreso nacional de la federación aliancista en marzo de 1977), ${ }^{8}$ más la UNE y ADE.

\section{LAS ASOCIACIONES POLÍTICAS}

El proyecto de asociaciones políticas dentro del Movimiento Nacional concluyó con la firma de Franco el 24 de diciembre del decreto-ley que regulaba las asociaciones, estipulando su entrada en vigencia para el 12 de enero de 1975. La sinuosa y accidentada trayectoria del marco regulador de las asociaciones políticas abierta, especialmente tras la aprobación de la Ley Orgánica del Estado (LOE) en 1967, llegaba tarde para una gran parte de la clase reformista franquista, entre ellos Fraga, a pesar de su predisposición posterior a participar. ${ }^{9} \mathrm{El}$ debate sobre las asociaciones políticas arrastraba la concepción sobre cómo debería evolucionar el régimen franquista y las diferentes metodologías existentes para llevarlo a cabo, siendo el papel político que debería llevar a cabo el Movimiento Nacional («Movimiento-Organización») uno de los ejes del debate. En este sentido, no es baladí la lucha abierta durante el primer gobierno de Arias Navarro entre el mismo presidente y el titular de la Secretaría General del Movimiento Nacional, José Utrera Molina, sobre quién debería controlar las futuras asociaciones políticas, a saber: el gobierno o el Consejo Nacional. ${ }^{10}$

El estatuto finalmente aprobado asumía la historia de la propia clase política franquista al no presentar ningún rescoldo de todo aquello que pudiera significar una desnaturalización del régimen a través de partidos políticos encubiertos en asociaciones. La base dogmática sería que las asociaciones políticas no serían partidos políticos, de ahí que Franco tuviese claro que el máximo órgano colegiado del Movimiento Nacional y principal responsable de mantener la ortodoxia de las Leyes Fundamentales, el Consejo Nacional, sería el garante de que ninguna asociación presentase veleidades contrarias al «espíritu del 18 de Julio» y al régimen que lo representaba. Es representativo de ello, que el régimen «evolucionase» desde sus instituciones, leyes y legitimidades hacia una actualización, que no era

${ }^{8}$ RPP, SGPIYPE, MI, carp. 244, "Certificado de inscripción de la Asociación Política Partido Unido de Alianza Popular», Madrid, 4 de mayo de 1977.

${ }^{9}$ Un seguimiento del proceso de codificación del Estatuto Jurídico al Derecho de Asociación Política puede seguirse, en M.A Giménez Martínez: El Estado franquista. Fundamentos ideológicos, bases legales y sistema institucional, Centro de Estudios Políticos y Constitucionales, Madrid, 2014, pp.113 -119.

${ }^{10}$ Los proyectos políticos contrapuestos, aunque no excluyentes, de Arias y Utrera, en F. Gallego: El mito..., cit., especialmente capítulos I y II. Una visión memorística, en J. Utrera Molina: Sin cambiar de bandera, Planeta, Barcelona, 2008, pp. 129 y ss. [ed. rev. y aum.]. 
otra cosa que mantenerse fiel a su propio desarrollo institucional desde la finalización de la Guerra Civil.

La ley de asociaciones -inserta en el contexto político del denominado «Espíritu del 12 de febrero» de 1974 y de la crisis abierta en el régimen tras la muerte de Carrero Blanco en diciembre de 1973-, partía del reconocimiento de las asociaciones como «medios complementarios para la participación de los españoles en las tareas políticas a través de las entidades naturales, a la vez que cauces de expresión de la opinión pública», siendo su función «la formulación ordenada de medidas y programas que se orienten al servicio de la comunidad nacional, el análisis crítico de los programas y soluciones concretas de Gobierno", así como «la permanencia y el perfeccionamiento del Movimiento Nacional, del ordenamiento jurídico y la mayor eficacia de la acción de Gobierno». Asimismo, se hacía hincapié en "la promoción de los españoles en tareas públicas», así como en "la formación y expresión de la opinión pública, procurando que la pluralidad de opiniones y el contraste de pareceres» se encauzara y desarrollara "al servicio del bien común y del reconocimiento de los derechos de la persona y su ejercicio». ${ }^{11}$

Por lo tanto, las asociaciones no substituirían ni al Partido Único (FET y de las JONS) ni serían nada parecido a un partido político; lo que se intentaba realizar era canalizar las culturas políticas franquistas en un proyecto dentro de las estructuras del Movimiento que facilitase la actualización de la mismas, pero siempre partiendo de la máxima que «las actividades de las mismas [asociaciones] y de sus órganos de gobierno se ajustarán a los Principios del Movimiento y demás Leyes Fundamentales del Reino». En este sentido, el Consejo Nacional se le asignaba acordar el reconocimiento de las asociaciones y de sus federaciones -así como su posible disolución-, y vigilar por el cumplimiento de la ley asociaciones. Por su parte, la Secretaría General del Movimiento Nacional completaría las tareas del Consejo Nacional recogiendo las solicitudes de las asociaciones para remitirlas posteriormente al Consejo Nacional, expendiendo certificaciones para las asociaciones, dirigiendo el Registro Nacional de Asociaciones Políticas y, finalmente, facilitando información en todo lo relacionado con las asociaciones políticas y su régimen jurídico. Por su parte, las asociaciones, para constituirse, debían presentar un mínimo de veinticinco mil firmas distribuidas como mínimo en quince provincias, con un mínimo de inscritos por provincia y, en el caso de celebrase «procesos electorales orgánicos» -concepto afirmado en la ley-, la condición para poder participar en las elecciones sería que en las circunscripciones existiese una sección provincial o local de dichas asociaciones. ${ }^{12} \mathrm{~A}$ su vez, el nombre de las asociaciones no podía coincidir con nombres o símbolos que formaban parte

${ }^{11}$ Archivo General de la Administración (AGA), Presidencia, Consejo Nacional del Movimiento (CNM), Libro de Sesiones del Consejo Nacional. Estatuto Jurídico del Derecho de Asociación Política, libro 946 (Artículos 1 y 4 del Estatuto).

${ }^{12}$ Ibid.; véase también C. Molinero y P.Ysàs: La anatomía del..., cit., pp. 214-215. 
del Movimiento Nacional o ser contrarios a ellos o a las Leyes Fundamentales del Reino. ${ }^{13}$ Finalmente, existía la posibilidad de multas y vetos a todas aquellas asociaciones que no respetasen el marco asociativo o constitucional franquista. ${ }^{14}$

A su vez, el nuevo estatuto de asociaciones sería completado legislativamente con la regulación de las propias asociaciones políticas cara la concurrencia electoral. Es por ello que las asociaciones plenamente reconocidas por el Consejo Nacional podrían presentar candidatos a las siguientes instituciones: a los órganos representativos del Movimiento (consejeros locales y provinciales), a las corporaciones locales (concejales, alcaldes, diputados provinciales, consejeros de cabildos, presidentes de diputación y de cabildos insulares, así como consejeros y presidentes de mancomunidades interinsulares), a procuradores en Cortes (sólo los referentes a rectores universitarios y alcaldes de las cincuenta capitales de provincia -incluidas Ceuta y Melilla, principalmente). ${ }^{15}$ Asimismo, el estatuto dejaba bien claro que ningún candidato podría presentarse como independiente a ninguna concurrencia electoral, siendo imperativo legal el «ser propuesto por una asociación reconocida». ${ }^{16}$ Por otro lado, también se reguló la presencia de las asociaciones en los medios de comunicación del Movimiento, disponiendo que los usos de tales canales informativos (prensa, radio y Televisión Española, exclusivamente a nivel provincial y regional) se circunscribirían a la exposición de fines y programas de las asociaciones plenamente reconocidas por el Consejo Nacional bajo el objetivo de apoyar a las candidaturas respectivas en las campañas electorales. ${ }^{17}$

${ }^{13}$ Tal fue el caso de la falangista Círculos Doctrinales José Antonio, encabezada por Diego Márquez, la cual solicitó el nombre de Falange Española y de la JONS para su asociación política falangista, alegando que el partido fascista había desaparecido con el Decreto Unificación de 1937, siendo el Movimiento Nacional cosa distinta. Finalmente, el Consejo Nacional se negaría a concederle el nombre al constituir un patrimonio constituyente del Movimiento; véase "Nota sobre la sesión celebrada por la Comisión Permanente el día 18 de julio de 1975», Boletín Oficial del Consejo Nacional del Movimiento (BOCNM), n. ${ }^{\circ}$ 84, p. 1803. Por su parte, Raimundo FernándezCuesta también pugnaría por el nombre del partido fascista, el cual no le sería otorgado hasta 1976; llegado el momento bautizó su asociación como Frente Nacional Español (FNE), teniendo problemas también, ya que su idea original de llamarse Frente Español fue denegada por el Consejo Nacional al entender que las siglas de ésta, «FE», se parecían al partido de José Antonio; de ahí que añadiera «Español» al nombre de Frente Nacional; «Nota sobre la sesión celebrada por la Comisión permanente el día 19 de agosto de 1975", BOCNM, n. ${ }^{\circ}$ 84, p. 1819.

${ }^{14}$ Entre las asociaciones que serían privadas de entrar en el marco asociativo por contradecir la legislación o ser ambiguas en sus documentos programáticos, podemos citar el caso de la asociación falangista de Barcelona Alianza Popular de Izquierdas o la asociación Democrática y de Paz Social; «Sesión plenaria celebrada el día 17 de noviembre de 1975», BOCNM, n. ${ }^{\circ} 85$, pp. 1832-1833.

${ }^{15}$ «Decreto 1970/ 1975, de 23 de agosto por el que se revisan con carácter general las condiciones que se exigen a las asociaciones políticas para su concurrencia electoral», BOCNM, n. ${ }^{\circ} 84$, p. 1768 (artículo segundo).

${ }^{16}$ «Decreto 1970/ 1975, de 23 de agosto para modificar disposiciones con fuerza de ley, en cuanto se considera necesario, para regular la comparecencia de las asociaciones políticas en la presentación de candidatos en los diversos procesos electorales (Disposición final dos del Decreto-Ley 7/1974)", $B O C M N$, n. ${ }^{\circ} 84$, p. 1770 (artículo primero).

${ }^{17}$ «Decreto 1972/1975, de 23 de agosto, por el que se regula la presencia de las asociaciones 
Finalmente, el desarrollo legislativo del marco regulador asociativo finalizaría, en apariencia, con la creación, bajo dependencia del Consejo Nacional, de una Oficina de Información del Derecho de Asociación Políticas y un Registro Nacional de Asociaciones Políticas, lugar, éste último, al que deberían dirigirse todas las futuras asociaciones para ser legalizadas. ${ }^{18}$

Para muchos la ley de asociaciones venía demasiado tarde y nacía literalmente casi muerta, aunque algunos hubiesen luchado por ellas, especialmente los reformistas franquistas «azules» como José Miguel Ortí Bordás, para el cual «el problema representado por el asociacionismo político, considerado insoluble durante mucho tiempo, acabó por pudrirse», ya que "las asociaciones políticas ya no eran una solución». ${ }^{19} \mathrm{La}$ ley dejaba insatisfechos a casi todos: a los sectores de la extrema derecha del régimen por permitir la desnaturalización del régimen; a los sectores más reformistas del régimen por considerarlo insuficiente; y, a la oposición democrática por considerarlo nulamente democrático y continuador de las esencias del régimen.

A pesar de ello, gran parte de asociaciones entrarían a «jugar» en el marco de la ley asociativa, entre ellas la gran mayoría de las constituyentes de la federación política de AP, como la «movimentista» UDPE -la primera en ser definitivamente aprobaba por el Consejo Nacional en julio de $1975-,{ }^{20}$ la tradicionalista UNE o la gubernamental ANEPA, por citar las más representativas. ${ }^{21}$ Por ello, es importante resaltar, junto a la LOE, la ley de asociaciones como uno de los orígenes de AP, ya que es la ley que permite la constitución de la mayoría de los partidos-asociaciones que formarán la plataforma aliancista en octubre de 1976.

\section{Fraga ANTE LAS ASOCIACIONES POLÍTICAS}

Fraga consideró la ley de asociaciones muy restrictiva, pero a la vez la interpretó como el comienzo de un posible futuro coherente con la esencia del franquismo. ${ }^{22}$ Por otro lado, las valoraciones realizadas por el Príncipe Juan Carlos a

políticas en los medios de comunicación social del Estado y del Movimiento», BOCNM, n. ${ }^{\circ}$ 84, p. 1771 (artículo segundo), y completada por la«Orden de 13 de octubre de 1975 por la que se dictan normas para la presencia de las asociaciones políticas en RTVE y en las emisoras del movimiento (REM-CAR)», BOCNM, n. ${ }^{\circ} 85$, pp.1850-1852.

${ }^{18}$ «Decreto 1973 / 1975, de 23 de agosto, por el que se aprueba el reglamento del Registro Nacional de Asociaciones Políticas y de la Oficina de Información del Derecho de Asociaciones Políticas", BOCMN, n. ${ }^{\circ} 84$, pp. 1772-1775.

${ }^{19}$ J.M. Ortí Bordas: La Transición desde dentro, Planeta, Barcelona, 2009, p. 173.

${ }^{20}$ M.A. del Río Morillas: «Unión del Pueblo Español (UDPE) ..., cit.

${ }^{21}$ Una recopilación sobre las diversas asociaciones políticas puede consultarse, en J. Conte Barrera: Las asociaciones politicas, ATE, Barcelona, 1976, y J. Gil Pecharromán: El Movimiento Nacional..., cit., pp. 193-232.

${ }^{22}$ Cabe recordar que Fraga estaba fuera de los resortes del poder franquista desde 1969, cuando fue cesado como ministro de Información y Turismo y posteriormente como Consejero Nacional. Entre 1971-1973, calificada como «la Primavera de Fraga» por uno de sus biógrafos (O. Cabezas: Manuel Fraga: semblanza de un hombre de Estado, Organización Sala, Barcelona, 1976), Fraga codificó 
Alfonso Osorio sobre la necesidad de formar un núcleo de reformistas franquistas de «centro-derecha» en el que estuvieran Fraga, Areilza y Silva Muñoz cara a un primer gobierno de la monarquía que ayudase a consolidar la institución monárquica, tuvieron un peso considerable para que Fraga estuviera predispuesto a entrar en el asociacionismo. ${ }^{23}$ Asimismo, una conversación entre el Príncipe Juan Carlos y Fraga, al respecto, ayudarían a disipar cualquier duda sobre su participación en el proceso asociativo. ${ }^{24}$ Ante este contexto político, Fraga planteó la posibilidad de crear una asociación, la cual contaría con el apoyo de Areilza, pero no con el de los sectores que más interesaban a Fraga: los de Joaquín Ruiz-Giménez y los de Francisco Fernández Ordóñez, respectivamente. ${ }^{25}$ Otro de los núcleos que también interesaban a Fraga, era el liderado por Joaquín Garrigues Walker, quien se negó en rotundo a formar parte del proyecto; éste publicó un artículo en $A B C$ el 30 de septiembre de 1975 atacando a Fraga por su intento de presentarse como «centrista» después de señalar trayectoria del político gallego dentro del régimen franquista. ${ }^{26}$

Ante este panorama, con una expectación considerable por parte de la prensa ${ }^{27}$ y con el «ciclón Fraga» u «operación Fragamanlis» -apodos de la prensa- con un nivel de popularidad bastante remarcable, ${ }^{28}$ Fraga se reunió con el gobierno de Arias llevando un proyecto de mínimos bajo el brazo (Borrador para un programa de acción política en la España de 1975), consensuado con GODSA, ${ }^{29}$ en el cual se

su teoría del «centro» (dentro de las coordenadas del régimen) a través de una frenética actividad intelectual apoyada por GODSA (Fraga se convertiría en el principal y único cliente, fundiéndose el proyecto de GODSA con la persona de Fraga) y su núcleo de colaboradores. De esa etapa de conferencias, inauguraciones y actos sociales con las élites franquistas salen a modo de reflexión política dos de sus más obras representativas, El desarrollo político (Grijalbo, Barcelona, 1971) y Legitimidad y Representación (Grijalbo, Barcelona, 1973), las cuales constituirían el eje doctrinal de su reformismo-centrista franquista. Posteriormente, entre 1973 y 1975, sería embajador en Londres, sin que ello fuera impedimento para poder participar en los círculos políticos del régimen.

${ }^{23}$ A. Osorio: Trayectoria política de un ministro de la Corona, Planeta, Barcelona, 1980, p.35.

${ }^{24}$ M. Fraga Iribarne: Memoria breve de una vida pública, Planeta, Barcelona, 1980, pp. 340-341.

${ }^{25}$ Ibid., p. 345.

${ }^{26} \mathrm{~F}$. Campuzano: L'élitefranquiste et la sortie de la dictature, L'Harmattan, París, 1997, p. 150.

${ }^{27}$ La expectación era continua en todos los viajes que Fraga hacía a España desde Londres. Es remarcable el movimiento mediático en la visita de Fraga para los «Premios de Periodismo Fraga Iribarne», en diciembre de 1974, creados por el «equipo catalán» de Fraga en 1973; véase la portada de La Vanguardia Española del 19 de diciembre de 1974, con la referencia a los citados premios de periodismo..

${ }^{28}$ M. Milián Mestre: Fraga Iribarne: retrato en tres tiempos, Dirosa, Barcelona, 1975, p. 356.

${ }^{29}$ GODSA nace como sociedad mercantil en 1973 gracias a los militares Javier Calderón, Jose Luis Cortina Prieto y Florentino Platero a modo de sociedad de estudios y asesoramiento político. Con el tiempo Fraga se convierte en su único y principal cliente, convirtiéndose en su think tank particular sobre el que estructurará, con la ayuda de los núcleos «fraguistas» de Barcelona -liderados por Milián Mestre y el Club Ágora- y de Madrid, el partido político RD. Las diferentes interpretaciones sobre los orígenes de GODSA han sido tratadas, en M.A del Río Morillas: De la extrema...cit., pp. 55-63. Una reciente visión memorística sobre los orígenes de GODSA, el Club Ágora y RD, en M. Milián Mestre: Els ponts trencats, Pòrtic, Barcelona, 2016; asimismo, puede seguirse en otro formato, en J.B. Culla: La dreta... cit., pp. 13 y ss. 
fijaba unos «mínimos políticos» para su participación en las asociaciones. En dicho documento, y sus posteriores evoluciones en forma de borrador -se llegaron realizar cinco-, se formulaba un reformismo franquista basado en la modernización del ordenamiento jurídico fundamental (Movimiento Nacional como amplio marco constitucional y el gradual desmantelamiento de sus instituciones; la creación de un Cortes bicamerales, con una cámara baja elegida por sufragio universal y una cámara alta de carácter corporativo elegido por sufragio indirecto) ${ }^{30}$ alejado de todo aquello que pudiera implicar o significar la apertura de un proceso constituyente.

Si interiorizamos más, nos encontramos con las teorías que Fraga había ido postulando desde 1970, a partir de 1973 con ayuda de GODSA, sobre su concepción de la "teoría del centro» en el marco "evolutivo-reformista» franquista. Su propuesta más novedosa fue la codificación de quiénes podrían formar parte políticamente de su proyecto «centrista» cuando llegara la hora del «hecho sucesorio»- la muerte de Franco- y el posterior «tránsito» político. En tales compañías, siempre partiendo de la búsqueda de la continuidad sin rupturas y de la actuación dentro de las Leyes Fundamentales, se incluía «desde la derecha evolucionista y moderna, hasta las posturas social-democráticas reformistas de origen cristiano y talante liberal». Queda claro que esa «socialdemocracia» y «derecha evolucionista» citadas, no podían ser otras que las interpretadas por GODSA. En este caso, la «socialdemocracia» era entendida como una variante de las tesis evolucionistas falangistas del Frente de Juventudes, mezcladas con parámetros socializantes de carácter nacional a «intramuros» y sin pretensión alguna de llegar a la ruptura con el régimen. ${ }^{31}$ Por su parte, «la derecha evolucionada» podría equipararse con la teorizada por Areilza en su concepción de «derecha civilizada», la cual, no era otra cosa que la derecha europea posterior a la Segunda Guerra Mundial que había incorporado a su corpus doctrinal el lenguaje de la democracia y abandonado las veleidades dictatoriales y antidemocráticas, respectivamente. ${ }^{32}$ Ciertamente, Areilza postulaba una homologación con la derecha democrática europea como superación de la Guerra Civil, pero partiendo del franquismo y sin ninguna ruptura clara, y en ningún caso, como la derecha que pudiera representar

\footnotetext{
${ }^{30}$ C.T. Powell: «Crisis del franquismo, reformismo y transición a la democracia», en J.Tusell, F. Montero y J.M. Marín (eds.): Las derechas en la España contemporánea, Anthropos, Barcelona, 1997, p. 261.

${ }^{31}$ Una parte de GODSA procedía de la denominada «izquierda nacional» del régimen de tendencia falangista y eminentemente nacional-sindicalista, revolucionaria y anticapitalista. El intento, sin romper con el régimen, de tránsito del falangismo del Frente de Juventudes a la «socialdemocracia nacional» estaría caracterizado por el fallido intento de Cantarero del Castillo y su asociación política Reforma Social Española (RSE); M.A del Río Morillas: De la extrema...cit., pp.56-59. Un análisis sobre la denominada «izquierda nacional», entre otros, en M.A Ruiz Carnicer: «Fascistas de "izquierda" en los setenta. La búsqueda de las bases populares para el proyecto de una izquierda nacional en la España de Franco", Rubrica Contemporanea, 5 (2014), pp. 71-87. Disponible on-line en: http://revistes.uab.cat/rubrica/article/view/v3n5-ruiz_carnicer

${ }^{32}$ J.M. de Areliza: Crónica de la libertad (1965-1975), Planeta, Barcelona, 1985, pp. 117-127.
} 
Gil-Robles. Por lo tanto, equiparar la derecha de un sistema democrático, como la derecha "gaullista» o la derecha cristiana alemana o italiana, con el deseo de crear una derecha procedente de un régimen de extrema derecha, sin ánimo de «hacer tabla rasa», puede llevar a errores ideológicos claros y confusiones varias. Areilza, como reformista franquista, pretendía organizar esa "derecha civilizada", cosa alejada del monolítico Movimiento, para que, en el caso que llegase un régimen democrático que partiese del franquismo -condición esta última sine qua non-, estuviese la derecha organizada en un talante homologable con las derechas europeas occidentales.

En lo referente a los sucesivos borradores de Fraga, especialmente el primero, se emitían postulados ya previamente «amasados» por el propio Fraga y los equipos de GODSA, y que, en general, partían de bases coherentes con las tesis evolucionistas y dinámicas del régimen. Entre la serie de propuestas que Fraga y su equipo proponían para poder «jugar» al asociacionismo de Arias destacan: la reforma como respuesta al inmovilismo y la revolución; la reforma parcial "constitucional» (de la Leyes Fundamentales); la reconciliación nacional; la defensa de un «Estado fuerte» y unitario que reconociera los factores geográficos, históricos, culturales y económico-sociales de las regiones; la forma monárquica del estado encabezada por el príncipe Juan Carlos -según lo dispuesto en la LOE-; la adopción del bicameralismo con cámaras elegidas por sufragio universal -una de forma exclusiva y la otra parcialmente-; o la potenciación de la «autoreforma» de las Fuerzas Armadas cara una mayor profesionalización -pero partiendo de su naturaleza de instrumento del «Estado Nacional» y recalcando que, por ser «guardianes» del «orden constitucional», no tenían derecho a intervenir en la vida política-. En lo referente al mundo laboral, se postulaba que los sindicatos «se organizaran con una representación auténtica en todos los niveles», reconociéndose, a su vez, el derecho a la huelga y a la autonomía de las representaciones obreras y empresariales; mientras que en política exterior se priorizaba el acercamiento a Europa y se apelaba «a los lazos de sangre y cultura» con la Hispanidad como "enlace con Europa». Finalmente, se defendía la educación pública, la potenciación de la sanidad pública y asistencia médica, y la defensa de la transparencia de los medios de comunicación, así como «una separación, amistosa, pero clara y total» entre el Estado y la Iglesia. ${ }^{33}$

Remarcar que la base de estos borradores para la propuesta de una asociación política, serían la esencia de los libros programáticos de GODSA /RD, Libro blanco

${ }^{33}$ Los borradores fueron recogidos por diferentes medios de comunicación. El primer borrador lo podemos encontrar resumido en la revista Cambio 16 correspondiente al 3-9 de febrero de 1975 bajo el título "El programa básico», siendo, asimismo, recogido y citado, entre otros, en M. Milián Mestre: Fraga Iribarne...,cit., pp. 358-366. El quinto borrador aparecería de forma completa en la revista Índice, correspondiente al 1-15 de octubre de 1975, bajo el título «El último programa del señor Fraga. Documento de trabajo para la preparación de una asociación política (quinta versión)», siendo recogido y citado, en M. Penella: Los orígenes..., cit., pp. 1106-1118. 
para la reforma democrática (GODSA, Madrid, 1976) y Llamamiento para una reforma democrática (GODSA, Madrid, 1976). Finalmente, el proyecto no fue aceptado ni por el gobierno ni por Franco, ${ }^{34}$ que lo consideraron demasiado "reformista», a pesar del deseo del propio Arias de que Fraga participase en el proceso asociativo bien a través de su asociación o bien a través de la asunción de la dirección de la «movimentista» UDPE. ${ }^{35}$ En la reunión entre el gobierno y Fraga, se animó literalmente a éste a que "podase» su borrador, dado que, aunque era bueno, las circunstancias del momento y el propio Franco no eran proclives para su aceptación inmediata. Ante tal lectura, Fraga se negó a "podarlo». ${ }^{36}$

En este sentido, y, en contra de las interpretaciones en pro del Fraga «demócrata-liberal» que se han fomentado desde la propia derecha española y que entroncan con interpretaciones historiográficas, periodísticas y memorísticas que hacen mención al «triunfo del reformismo franquista» como portador de la democracia española -a la par que se infravalora la importancia de las movilizaciones sociales en el proceso, la "crisis orgánica» del franquismo y la correlación de fuerzas- ${ }^{37}$ no fue Fraga quien se negó a participar en el «juego de las asociaciones» por considerarlo, utilizando la terminología del momento, «demasiado estrecho», sino que fue el propio régimen quien vetó su participación, después de intentar infructuosamente «podar» su borrador.

Previamente a estos hechos, cabe hacer referencia a la expectativa levantada por el gobierno Arias ante la posible alianza Fraga-Silva-Areilza, la «Santa Alianza o "Triple Alianza», cara la constitución de una asociación política que reuniera a los tres políticos. Especialmente para Arias, la posible alianza podría dotar de prestigio "reformista», a la par que potenciar, el naciente asociacionismo franquista. ${ }^{38}$ Según Alfonso Osorio, uno de los promotores de la «Santa Alianza», no se llegó a un acuerdo porque Fraga solamente hablaba de su programa político y su posible aceptación por parte del gobierno, sin que se hablara para nada de crear una asociación conjunta, cosa que Osorio pretendía al revés, primero crear una

\footnotetext{
${ }^{34}$ Franco le manifestó a Nieto Antúnez su negativa a aceptar el proyecto de Fraga y todo lo que él representaba: «No a Fraga, que pretende alzarse con la herencia»; R. Baón: Historia del Partido Popular I. Del Franquismo a la Refundación, Ibersaf, Madrid, 2001, p. 67.

${ }^{35}$ Fraga se negó a asumir la presidencia de la UDPE, siendo Adolfo Suárez quien asumiría posteriormente la presidencia; M.A. del Río Morillas: «Unión del Pueblo Español (UDPE) ..., cit.

${ }^{36}$ M. Fraga Iribarne: Memoria breve..., cit., pp. 346-347; J. Tusell y G. G. Queipo de Llano: Tiempo de incertidumbre. Carlos Arias Navarro entre franquismo y la Transición (1973-1976), Crítica, Barcelona, 2003, pp. 157-159.

${ }^{37}$ Algunos ejemplos los encontramos, en M. Fraga Iribarne: Memoria breve..., cit.; P. y A. Miranda: Lo que el Rey me ha pedido:Torquato- Fernández Miranda y la reforma, Plaza \& Janés, Barcelona, 1996 (siguiendo la saga familiar y el mismo relato, J. Fernández-Miranda: El guionista de la Transición. Torcuato FernándezMiranda, el profesor del Rey, Plaza \& Janés, Barcelona, 2015);V. Prego: Así se hizo la democracia, Plaza \& Janés, Barcelona, 1995; R. Baón: Historia del Partido..., cit.; C. Palomares: Sobrevivir después de ..., cit.; G. Elorriaga Fernández: Fraga y el eje de la transición, Cuadernos del Congreso de los Diputados, Madrid, 2014.

${ }^{38}$ Véase, a modo de ejemplo, "Listos para el partido», Cambio 16,3-9 de febrero de 1975.
} 
asociación y después hablar de un programa político. Por su parte, según Osorio, Federico Silva estaba muy receloso de quién sería el líder de la posible asociación, queriendo liderar el futuro pacto de los tres políticos. Asimismo, recalca que, la ausencia de Silva en una conferencia que Fraga realizó en el Club Siglo XXI, debido a presiones de Marcelino Oreja y Cabanillas, sentó mal a los miembros de GODSA, los cuales influenciaron sobre la decisión de Fraga. ${ }^{39}$ Anteriormente a la reunión entre los cuatro políticos, el equipo de GODSA había acordado con Fraga que no se realizasen pactos a la derecha de éste, tipo Silva Muñoz o Fernández de la Mora, y que en todo caso solo se abría hacia el «centro-izquierda». ${ }^{40} \mathrm{La}$ primera entrevista que tuvieron Silva y Fraga, a raíz de la «Santa Alianza», finalizó con la idea que cada uno tendría que preparar su propio proyecto, en vez de unirse en una sola asociación, y que en un futuro ya se encontrarían para hacer frente a «los marxistas» (Fraga acertó el futuro ya que ambos se encontrarían en AP). La entrevista final, que tuvo lugar el 25 de enero de 1975 entre los cuatro políticos, es conocida como finalizó por las memorias de Silva. Fraga finiquitó rápidamente la reunión sin que se llegase a ningún acuerdo, a la par que sugirió toscamente las palabras que sus anfitriones deberían decir a la prensa sobre la reunión mantenida: "Que hemos hablado, que seguiremos hablando y que no tenemos nada que decin. ${ }^{41} \mathrm{El}$ fracaso del pacto «reformista» también fue recogido por la prensa del momento, resaltando la opción perdida para el desarrollo de una asociación fuerte y aglutinadora del «centro reformista franquista». ${ }^{42}$ Es curioso señalar que, la frustrada «Santa Alianza» renacería en 1979 cuando los tres políticos -pero en ese momento Osorio substituyó a Silva- confluyeron en la formación política Coalición Democrática (CD) para concurrir a las elecciones generales de 1979. CD estaría integrada, entre otros, por AP, Acción Ciudadana Liberal (ACL) de Areilza y el Partido Democrático Progresista (PDPr) de Osorio.

Respecto a la presencia de Fraga en Madrid durante enero de 1975, es remarcable la visión que José María Velo de Antelo, futuro vicepresidente del primer Congreso de AP y vicepresidente ejecutivo de la UNE, tenía sobre el Fraga que presentó los borradores para una futura asociación. En un almuerzo en el Club Siglo XXI, Fraga presentó su borrador ante una concurrencia de personas, obteniendo una gran aceptación a su proyecto, incluso recibiendo palabras efusivas

\footnotetext{
${ }^{39}$ A. Osorio: Trayectoria política..., cit., p.36.

${ }^{40}$ M. Penella: Los orígenes..., cit., p. 67.

${ }^{41}$ F. Silva Muñoz: Memorias políticas, Planeta, Barcelona, 1993, pp. 302-307.

${ }^{42}$ Argos: «Sin coalición el centro naufraga», $A B C, 1$ de febrero de 1975.
} 
como las de Areilza, que afirmaba, que iría con Fraga a cualquier parte. ${ }^{43}$ Solamente Velo Antelo se manifestó negativamente a su proyecto:

"Yo no estaba de acuerdo, porque todo lo que escuché, en gran parte irritante coba, sin el más mínimo sonrojo del adulado ni los aduladores, saqué la conclusión de que lo que allí se estaba gestando era la vuelta a la democracia demoliberal, al sistema político que tantas tragedias había traído a España y que no parecía que fuera lo más beneficioso para nuestro futuro». ${ }^{44}$

Aquí podemos ver otra pequeña muestra que corrobora que, parte de los futuros integrantes de AP, como Velo Antelo, claramente situados en la ortodoxia del régimen, estaban situados a la derecha de Fraga. Es por ello que la constitución de la plataforma aliancista, estuvo marcada, primordialmente, por la dinámica del continuismo franquista, la cual nada tenía que ver con parte del «intrareformismo» defendido por Fraga, ni por el Fraga más autoritario del primer gobierno de la monarquía. Personajes como Fernández de la Mora o Velo Antelo veían en el borrador de Fraga de 1975 una desnaturalización del régimen, aunque el citado borrador era coherente con la esencia del franquismo ya que se defendía el mantenimiento del Movimiento Nacional como «marco constitucional» y «la Monarquía del 18 de Julio» codificada en la LOE, a la par que se criticaba cualquier propuesta de ruptura con el régimen. Parte de la extrema derecha del régimen que formaría parte de AP, claramente, era refractaria a todo discurso que supusiese un cambio en las estructuras de éste, aunque fuesen promocionadas desde dentro, siendo su paso por la política de la Transición una mera tarea defensiva y de ataque a todo aquello que supusiera una pérdida del control del proceso político y de los privilegios obtenidos a lo largo de la dictadura franquista.

Fraga regresó a Londres y afirmó a la prensa que daría una futura respuesta a su posible participación en el asociacionismo, sabiendo ya, de antemano, que su decisión había sido tomada como consecuencia de la negativa del gobierno y de Franco a sus demandas mínimas de participación política. El político gallego se quedaría en Londres hasta la muerte de Franco, desde donde siguió difundiendo su ideario a través de GODSA y FEDISA (Federación de Estudios Independientes S.A.), ${ }^{45}$ de sus publicaciones (Un Objetivo Nacional, Dirosa, 1975), así como a través de sus conferencias. Al mismo tiempo que realizaba estas actividades inició

${ }^{43}$ M. Fraga Iribarne: Memoria breve..., cit., p. 347.

${ }^{44}$ J.M.Velo de Antelo: De ayer a hoy. Los orígenes del Partido Popular, Galland Books, Madrid, 2010, p. 87.

${ }^{45}$ FEDISA fue una sociedad anónima encubridora de actividad política promovida por el «tácito» José Luis Álvarez (véase al respecto J.L.Álvarez: España desde el centro, Espasa / Calpe, Madrid, 1978). Formaban parte de ella políticos reformistas del franquismo como Areilza, Calvo Sotelo, Fernández Ordóñez o Marcelino Oreja, entre otros, destacando un especial contingente de miembros de Tácito; S. Míguez: La preparación de la transición a la democracia en España, Prensas Universitarias de Zaragoza, Zaragoza, 1990, pp. 180-183. Una reciente visión memorística de Tácito y de los sectores católicos reformistas del régimen, en J.A. Ortega Díaz-Ambrona: Memorial de transiciones (1939-1978). La generación del 1978, Galaxia Guttemberg, Barcelona, 2015. 
los pasos para estructuró su propio partido político, RD, presentándolo como una plataforma para aglutinar a las distintas fuerzas «centristas» del franquismo. Este "centrismo» intentaría identificarse con las clases medias que se habían formado en el «desarrollismo económico» de los sesenta, las cuales desearían un proceso de modernización democrático del país, sin llegar a ninguna ruptura política que paralizase económicamente y políticamente al país o que propiciase la perdida de los «logros» que habría reportado el franquismo a esas clases. Se planteaba, pues, un «centrismo reformista» que quería modernizar el sistema, no romper con él.

\section{Proyecto De UnA MACROASOCIACIÓN DEL MOVIMIENTO NACIONAL: ¿LOS ORÍGENES DE AP?}

Previamente al nacimiento de AP, mientras Fraga y sus «equipos» de trabajo intentaban, como hemos visto más arriba, crear un borrador para la constitución de una asociación política, otros representantes de la élite política franquista se reunieron continuadamente para dar forma a una macroasociación o una federación que defendiera a capa y espada las bases de unión del Movimiento Nacional y las Leyes Fundamentales que lo informan, o si se quiere decir de otra manera, las esencias del régimen franquista. En estas reuniones, que se realizaron especialmente a partir del estudio del estatuto de asociaciones de 1974, se postuló la formalización de asociaciones en el marco vigente y la posible federación posterior como fórmula para defender el franquismo y sus legitimidades de toda una amalgama de versiones de aperturistas que estaban teniendo un protagonismo destacado en la vida pública española. Se concebía el método de las asociaciones, no como un instrumento de desarrollo y evolución política, sino como un nuevo utensilio defensivo que completaba la «democracia orgánica» franquista, pudiendo ser de utilidad para defender el régimen del 18 de Julio en los nuevos tiempos imperantes. En cierta medida, la utilización de las asociaciones parece hecha a regañadientes y sin ninguna idea, ni deseo alguno, a que ninguna de ellas pudiese evolucionar hacía algo parecido a un partido político que ayudase a desnaturalizar o erosionar el régimen. Estas reuniones se realizaron más como acto defensivo, ante el auge público del «reformismo»y todo aquello que pudiese derivar hacia una posible ruptura, que como propuesta política alternativa. De estas reuniones continuadas, de la cuales nunca participó Fraga, saldría la idea base de la constitución de AP como representante más próximo al continuismo que al reformismo. Remarcar que, las circunstancias del momento no deseadas, serían el detonante para que 
AP se constituyese en formación política en octubre de 1976, a regañadientes de muchos de los propios promotores y como mal menor:

«Durante el año 1976 se suponía que, con sus diversos matices, las asociaciones iban a competir dentro del propio Movimiento Nacional, conforme a la LOE de enero de 1967, y al Estatuto Jurídico del Derecho de Asociaciones Políticas aprobado el 21 de diciembre de 1974. Sin embargo, los acontecimientos irían de manera muy distinta a la prevista, con situaciones muy difíciles de afrontar, debido a la interesada precipitación de las disposiciones legislativas del gobierno de Suárez, aprobadas en el primer trimestre de 1977. El paso a los partidos políticos se había dado, y las asociaciones políticas, ya en el fondo y en la forma partidos políticos, no tenían otra alternativa que entrar en el nuevo juego creado, lo que suponía obviamente la ruptura con el Régimen franquista, por más que sus promotores lo negaran, por alejar de ellos el peor estigma que cabe en supuestas personas leales». ${ }^{46}$

Nuevamente, el citado ejemplo de Velo Antelo nos puede ayudar a arrojar otra tesis sobre la formación de AP alejada de las defendidas por parte de Fraga y GODSA y parte de la actual derecha española, a saber: que AP no se constituyó como una fuerza aglutinante de la derecha "democrática» de origen franquista (un oxímoron en sí mismo) constructora de democracia, sino que AP se estructuró como una plataforma política -sin relación alguna con la colaboración en la «traída de la democracia» o las ansías democráticas de sus integrantes- nacida para hacer frente al «rupturismo» de izquierdas y de derechas a través de la defensa de todo lo que pudiese ser exponente de la «obra y herencia de Franco»:

«Alianza Popular no surgió por la simple decisión de unos políticos franquistas, ministros de Franco, que, en su día, optaron por crear diversas asociaciones políticas dentro del Movimiento Nacional, y posteriormente federadas en un partido político, sino por algo mucho más trascendental. Se trataba de asumir la nueva situación política creada a la muerte de Franco y, por consiguiente, de la necesidad de crear varias asociaciones políticas, pronto partidos políticos, que aliados, pudieran competir contra los partidos de izquierda y de la derecha rupturista, en las elecciones generales que lógicamente tendrían que convocarse, visto el panorama político creado por los dos gobiernos de Arias y, sobre todo, por el primer gobierno de Adolfo Suárez». ${ }^{47}$

Continuando, y referente a lo anteriormente citado sobre las reuniones de las futuras asociaciones que integrarían y constituirían $\mathrm{AP}$, cabe subrayarlas reuniones

${ }^{46}$ J.M.Velo de Antelo: De ayer a..., cit., p.16.

${ }^{47}$ Ibid.,p.15. Esta idea también la defiende el ex procurador sindical franquista y miembro destacado de la UDPE, Noel Zapico, el cual afirma que el proyecto germinal de AP se formalizó mucho antes de que Fraga liderase la misma plataforma aliancista: «colaboré en aquella etapa (...) para que Manuel Fraga se incorporase a nuestro proyecto, Alianza Popular»; J. de Ávila y J.Vélez: «Noel 
lideradas por José María Velo de Antelo a partir de mayo de 1974. Velo Antelo tenía claro que la derecha franquista tenía que organizarse en un núcleo duro que representase un germen de asociación a partir de la cual se aglutinara la derecha continuadora del franquismo en su versión defensora del Movimiento Nacional. La idea de Velo Antelo era muy clara:

"Yo estaba convencido de que había que unir fuerzas y que todos los que de alguna manera formaban parte del Movimiento Nacional no tenían más remedio que entenderse para crear una asociación política que pudiera hacer frente a una oposición de derechas ajena al Régimen, y, desde luego, al largo espectro de la oposición izquierdistas, que iba desde el socialismo radical de Tierno Galván a la extrema izquierda». ${ }^{48}$

En esas reuniones, que se iniciaron el 17 de mayo de 1974, asistieron, intermitentemente, la base del franquismo político más reticente a todo lo que hiciese referencia a reforma o aperturismo, representado en las figuras más destacadas del núcleo más duro del falangismo, tradicionalismo e integrismo tecnocrático, respectivamente. En este sentido, estuvieron presentes personalidades tan destacadas como José Antonio Girón de Velasco, Fernández-Cuesta, Manuel Valdés Larrañaga, Jesús Suevos, Carlos Pinilla, Francisco Labadié Otermín, Laureano López Rodó, Gonzalo Fernández de la Mora, el marqués de Valdeiglesias, José María de Oriol, José Luis Zamanillo, Thomas de Carranza o el propio Velo de Antelo. ${ }^{49}$ Las conversaciones se centraron en un análisis, en versión catastrofista, de la situación política y en la posible unificación de las fuerzas del 18 de Julio en una única asociación, pero pronto existieron diferencias al respecto. Por parte de FernándezCuesta, su idea básica era crear una asociación exclusivamente falangista sin la inclusión de otros grupos no falangistas, aunque no cerraba puertas al apoyo de todo lo que significase unir esfuerzos. Por parte de Oriol y Fernández de la Mora, se postulaban en constituir una gran asociación que integrase a todas las fuerzas del Movimiento, para llegados el momento, poder hacer frente al marxismo y a la democracia cristiana. Finalmente, el marqués de Valdeiglesias, se decantaba por realizar una asociación que resucitase el espíritu de Acción Española. A parte de las tendencias de cada uno, también existían reticencias personales como las que podían tener Girón de Velasco y José María de Oriol, los cuales chocaban en te-

Zapico, un langreano, ex minero y ex sindicalista, adjunto al Procurador General del Principado» (entrevista a Noel Zapico), La Hora de Asturias, 2 de agosto de 2006.

${ }^{48}$ Ibid., p. 93.

${ }^{49}$ López Rodó se integraría en las reuniones a partir del 23 de diciembre de 1974; L. López Rodó: Claves de la transición. Memorias (IV), Plaza \&Janés, Barcelona, 1993, p.97. Mientras López Rodó realizaba contactos en aras de una federación de fuerzas del 18 de Julio, también mantuvo contacto con Areilza sobre la posibilidad de una futura unificación de fuerzas entre él, Areilza, Fraga y Silva Muñoz con el objetivo de construir una «democracia desde arriba» que pudiese serle de utilidad al príncipe Juan Carlos (p. 159). 
mas relacionados con la organización socio-económica en el mundo franquista, ya que uno representaba la lectura más «revolucionaria» del falangismo y el otro representaba el espíritu más «conservador» del tradicionalismo.

Finalmente, después de algunas reuniones en que primero prevaleció la idea de crear asociaciones diversas - cada una con su propia personalidad- cara una futura federación, se codificó, a finales de 1974, el objetivo de organizarse en tres asociaciones diferentes pero unificadas con un secretariado compuesto por Valdés Larrañaga, Labadié Otermín, Thomas de Carranza y Velo de Antelo, asignando a éste último el cargo de coordinador de los tres grupos políticos. A lo largo de 1975, y especialmente a partir de 1976, se fueron incorporando otras personalidades del régimen a las reuniones, entre la que destacaron Silva Muñoz, Sánchez Bella o López Bravo, a lo que ya se llamaba «el Pacto de Torredolones» por tener lugar las reuniones en la casa que tenía Velo de Antelo en aquella localidad madrileña. Sobre la idea inicial de la constitución de tres asociaciones del Movimiento Nacional para posteriormente federarlas -primero se pensó en la UNE, la UDPE y en el sector de la UDE más afín a Silva Muñoz-, se fueron uniendo otras asociaciones para la posible alianza, como ANEPA, el germen de AR de López Rodó -que se constituiría primero en el Grupo Parlamentario Regionalista- ${ }^{50}$ el germen de DS de Licinio de la Fuente, el tradicionalista Frente Institucional (FI) de Ramón Forcadell o el FNE de Fernández-Cuesta -aunque ésta última prestaba más apoyo «moral» a la futura federación que intención real por integrarse-.${ }^{51}$

Paralelamente, también existían vasos comunicantes, por parte de algunas asociaciones de las anteriormente citadas asociaciones- especialmente el FNE, la UNE y ANEPA-, cara la formalización de otra plataforma que agrupase a otros sectores de la extrema derecha del régimen más radicales -como la integrista FN de Blas Piñar; la coordinadora fascista Movimiento Nacional Revolucionario (MNR), que agrupaba a grupos como el neonazi Círculo Español de Amigos de Europa (CEDADE) o la tradicionalista Agrupación de Estudiantes Tradicionalistas (AET); la carlista Comunión Tradicionalista (CT) o la Confederación Nacional de Ex Combatientes-, en torno al extremista Partido de Acción Nacional (PAN) ${ }^{52}$ El PAN, liderado por sus dos promotores Emilio de Miguel Moreno y

${ }^{50}$ Véase, M.A. del Río Morillas: «Acción Regional...cit.

${ }^{51}$ J.M. Velo de Antelo: De ayer a..., cit., pp. 93 y ss. Las reuniones entre las futuras asociaciones de AP se pueden seguir en la prensa del momento, véase «Cuatro asociaciones políticas han constituido un frente electoral», La Vanguardia Española, 13 de mayo de 1976; «UDPE, ANEPA, FN y UNE. Declaración de principio del nuevo pacto electoral», $A B C, 25$ de mayo de 1976; «UNE, FI, ANEPA y UDPE reiteran que su alianza se debe únicamente a fines electorales», La Vanguardia Española, 12 de junio de 1976; «"No hemos establecido ninguna alianza para derrocar el al actual gobierno", (señor Carvajal)", La Vanguardia Española, 22 de junio de 1976; «UNE aceptar participar en una confederación o alianza con otras fuerzas políticas afines», La Vanguardia Española, 13 de julio de 1976.

${ }^{52}$ "Así nace la "Platajunta” fascista», Cuadernos para el Diálogo, 5-11 de junio de 1976; «El Partido de Acción Nacional pretende una alianza de todos los grupos de extrema derecha", La Vanguardia Española, 12 de junio de 1976. 
Carlos-Emilio Rodríguez López, era un fiel representante de la extrema derecha neofranquista de corte «resistencialista» nacido «del espíritu que animó el Movimiento Nacional de 18 de Julio de 1936» y «adherido a la monarquía tradicional, católica, social y representativa», sintiéndose "heredero de los ideales del 18 de Julio que unieron a los españoles en la defensa de la liberad y de la identidad nacional contra el comunismo». De esa manera se describía el propio PAN a inicios de 1976, aferrándose a la propia historia que había forjado el franquismo inicial y que bien podría suscribirla FN o la Confederación Nacional de Ex Combatientes de Girón de Velasco, a la par que realizaba un llamamiento todas las «fuerzas nacionales» en aras de la unión en un mismo frente alrededor del PAN. ${ }^{53} \mathrm{El}$ intento aglutinante del PAN no fructificó, disipándose poco a poco bajo la excusa de no querer constituir una fuerza disgregadora de la derecha, aunque sin cesar de hacer comunicados públicos animando a la unión de todos los grupos «nacionales» en un único frente. ${ }^{54}$

En este sentido, el proceso de unificación de fuerzas se fue acelerando a partir de 1976, especialmente a partir de los actos acontecidos durante el primer trimestre de 1976, cuando las movilizaciones sociales fueron una constante. En este sentido, cabe destacar que, Fraga, en esos instantes, desde el Ministerio de la Gobernación seguía apartado (oficialmente en una segunda línea) tanto de la estructuración de su RD como partido político como del proceso de confluencia de las asociaciones políticas franquistas que estamos relatando. En ese contexto desde las propias estructuras franquistas, especialmente desde el Consejo Nacional, se incentivaron las reuniones para constituir un frente común de organizaciones políticas franquistas nacidas a partir de la ley de asociaciones de 1974 que sirviera de contraofensiva institucional a los posicionamientos rupturistas que estaban apareciendo públicamente a través de la oposición democrática y las constantes movilizaciones sociales. ${ }^{55}$ En este camino de unión de las fuerzas neofranquistas, el punto de inflexión, del cual se beneficiaría la futura alianza de fuerzas que sería la AP, fue el manifiesto conjunto realizado por tres de las futuras organizaciones que formarían AP (UDPE, ANEPA y UNE) más el FNE. El manifiesto era un alegato neofranquista de defensa institucional, especialmente el representado por

${ }^{53}$ AGA, Cultura, MIT. Gabinete de enlace, c.9152, Nota interior del Partido de Acción Nacional («Declaración pública de la comisión promotora del Partido de Acción Nacional ofrecida el 1 de enero de 1976»), Madrid, 1 de enero de 1976.

${ }^{54}$ «Suspendido el congreso del Partido de Acción Nacional. Llamamiento a UNE, UDPE, ANEPA, Falange y Comunión Tradicionalista para lograr una coordinación», La Vanguardia Española, 1 de julio de 1976. Referente al PAN, el partido ofreció su presidencia a Fernández de la Mora y su posible fusión con la UNE; «El Partido de Acción Nacional ofrece su presidencia a Fernández de la Mora» $A B C, 29$ de septiembre de 1976.

${ }^{55}$ AGA, Cultura, MIT. Gabinete de enlace, c.8899, Dosier sobre la asociación ANEPA, «ANEPA, UDPE, UNE y FNE se reunieron en el Consejo Nacional el día 9 de febrero de 1976», Madrid, 9 de febrero de 1976. 
las cúpulas más «resistencialistas» del franquismo -como era el Consejo Nacional-, ante el proceso reformista que estaba liderando el gobierno Arias-Fraga. Un proceso reformista que, aparte de estar siendo superado por las movilizaciones sociales, pecaba de limitado y de continuista, aunque acertadamente coherente con «democracia a la española» que deseaba Arias Navarro. ${ }^{56}$

Volviendo al texto, este era una advertencia al gobierno y al proceso reformista que lideraba, instándoles a ser fieles a la doctrina e historia del régimen, en tanto en cuanto los métodos de «adaptación», «evolución» y "perfeccionamiento» que el sistema tenía y que había utilizado a lo largo del régimen, no deberían confundirse con ningún objetivo que pudiera debilitar el «orden constitucional» franquista vigente. Por lo tanto, aunque se defendía que las reformas del gobierno eran necesarias, estas deberían seguir siempre fieles a las esencias institucionales que el régimen había estado desarrollando a lo largo de cuarenta años ${ }^{57}$ En el manifiesto firmado por Javier Carvajal (UDPE), Thomas de Carranza (ANEPA), José María Valiente (UNE) y Raimundo Fernández-Cuesta (FNE) se podía leer lo siguiente:

"Respetando las legítimas interpretaciones que puedan proponerse para el futuro de la vida española, reclamamos la defensa de la legalidad, cuyo respeto, sin condicionamientos ni reticencias, debe presidir en todo momento la vida de un estado de derecho, recordando la imperiosa necesidad de que las leyes se cumplan, sin que pueda producirse un vacio legal, al confundir la expectativa de una proyectada legalidad con la legalidad vigente. $Y$ sin que nadie pueda servirse de anuncio de un talante renovador y perfectivo que compartimos $y$ de una propuesta de gobierno que respetamos para presuponer soluciones y decisiones que son de la competencia de los legítimos órganos legisladores de la nación. Cualquier otra actitud supondría un grave atentado a la continuidad de estado y a la pacífica convivencia de los españoles. Deseamos para España un nuevo periodo de paz, de prosperidad y de concordia social, bajo el signo de la corona, en la que la sociedad española siga su camino de constante perfeccionamiento social, político $y$ económico, adecuando el pasado al futuro; incorporando nuevas ideas y valores y logrando las más altas y ambiciosas metas, desde la afirmación de la legitimidad de nuestras instituciones y del más absoluto respeto de las leyes. Dentro de este marco todo progreso

\footnotetext{
${ }^{56}$ Las limitaciones del propio proceso reformista del binomio Arias-Fraga, las resumiría el propio Fraga en una frase ante las Cortes franquistas el 21 de enero de 1976: «En términos más simples continuidad y lealtad al pasado solo son compatibles con el cambio, con la reforma, pero solo se reforma aquello en lo que se cree»; M.A. del Río Morillas: «Manuel Fraga y el primer Gobierno de la Monarquía (19751976)», en M. Loff y C. Molinero (eds.): Sociedades en cambio: España y Portugal en los años setenta [CD-ROM], CEFID-UAB/IHBC, Barcelona, 2012.

${ }^{57}$ Este posicionamiento de advertencia se tornaría cada vez más defensivo y beligerante ante las reformas del primer gobierno de la monarquía, como remarcaría, más adelante, el 13 de mayo de 1976 en Barcelona, el tradicionalista de la UNE, José Zamanillo al decir que, «la herencia del 18 de Julio no tiene protección como consecuencia de la falta de autoridad del Estado»; AGA, Cultura, MIT. Gabinete de enlace, c.8903, Dosier sobre la Agrupación Política Unión Nacional Española, «Nota interior del Agrupación Política Unión Nacional Española», Madrid, 13 de mayo.
} 
y toda esperanza será posible. Con su ruptura solo es previsible la destrucción del bien inapreciable de la paz. (...)».58

Este primer manifiesto conjunto se complementaría, más adelante, con un comunicado de fusión electoral entre las mismas organizaciones políticas neofranquistas a partir de la creación de una comisión conjunta como medio de actuación cara las futuras elecciones. El comunicado volvía a ser un alegato neofranquista englobado en las coordenadas de la extrema derecha nacional-populista mezcladas con tesituras «resistenciales», donde lo que se proponía era continuar con la herencia del franquismo adaptándola a los tiempos imperantes. No se pretendía renegar del régimen franquista, aunque ello no era sinónimo de querer perpetuar ni restaurar el régimen exactamente como podía ser en su etapa augural de corte más fascista. El texto explicativo de la fusión se iniciaba con palabras de recuerdo a Franco y a su «ingente obra», siendo el objetivo principal de la fusión electoral el «adecuar la herencia recibida por el pueblo español a las exigencias de las nuevas circunstancias de la sociedad», las cuales habían «nacido del desarrollo y progreso alcanzado en el fecundo periodo de paz vivido en España en las últimas décadas». El propósito compartido por las organizaciones firmantes se concretaba en «lograr sin ruptura ni riesgo, la construcción de un futuro esperanzador para la sociedad española, plural y participativa sobre la base de la institución monárquica», todo ello para crear «una España independiente asentada en la libertad y dignidad del hombre dentro de un planteamiento que se haga eco de la diversidad regional de las tierras españolas integrada en la unidad de la patria». El texto, que volvía a ser firmado por los mismos representantes que firmaron el primer comunicado conjunto de 11 de febrero de 1976, constituía la semilla operativa de un auténtico «Frente Nacional» aglutinador de las fuerzas derivadas del 18 de Julio en un nuevo contexto histórico encabezado por Juan Carlos. Asimismo, el alegato en pro de la legalidad franquista y en contra de todo aquello que intentase diluir o distorsionar los cauces estipulados para el perfeccionamiento del «Estado Nacional», ya fuera a partir de un «reformismo malentendido» o de la pura ruptura defendida por la oposición democrática, se erigía como la piedra angular del manifiesto. ${ }^{59}$

Incluso el tono de los firmantes se radicalizaría en ciertas zonas de la geografia española, concretamente en Santander. Allí los posicionamientos de la extrema derecha nacional-populista se inclinaron hacia posicionamiento de extrema derecha neofranquista del tipo «resistencialista» y «guerracivilistas». Claro está que ambas representaciones de la extrema derecha neofranquista española, la nacio-

${ }^{58}$ AGA, Cultura, MIT. Gabinete de enlace, c.8903, Dosier sobre la Agrupación Política Unión del Pueblo, "Comunicado conjunto de UDPE, ANEPA, UNE y FNE, Madrid», 11 de febrero de 1976.

${ }^{59}$ AGA, Cultura, MIT. Gabinete de enlace, c.8899, Dossier sobre la asociación ANEPA, "Comunicado conjunto ofrecido a los medios de comunicación y a las agencias de noticias», Madrid, 24 de mayo de 1976. 
nal-populista y la «resistencialista», no eran contradictorias y presentaban vasos comunicantes y, por lo tanto, no debería sorprendernos que incluso firmasen manifiestos conjuntos. No hay que olvidar ambas defendían en esencia lo mismo, el franquismo, pero en diferentes «versiones»: uno, el franquismo más ortodoxo de primera época (el de los años cuarenta y cincuenta) y, el otro, el «desarrollista» (el de los años sesenta).

El citado manifiesto estaba firmado por la «Coordinadora montañesa de Fuerzas Nacionales», la cual integraba las secciones regionales santanderinas de ANEPA, UNE, UDPE y FNE, mientras que contaba con el apoyo de la CT, la Confederación Nacional de Ex Combatientes, Vieja Guardia y antiguos miembros del Frente de Juventudes. El texto era un decálogo constituido por ocho puntos programáticos para la provincia de Santander, que partían «de una radical fidelidad a los ideales del 18 de Julio». El manifiesto era una amalgama de lo más representativo de la historia del lenguaje político franquista de tendencia «azul», donde conceptos como la "unidad de España», la lucha contra el materialismo, el comunismo y el capitalismo financiero se mezclaban con los "cantos joseantonianos» en pro de la justicia social, la juventud o la necesaria «reestructuración del campo español». Todo ello iba acompañado de un llamamiento al respeto a la legalidad vigente y a su historia, representada en Franco y en la herencia recibida por Juan Carlos mediante el juramento de las Leyes Fundamentales. Su alegato alejado de ambigüedades no dejaba lugar a dudas sobre los parámetros a seguir: «queremos una España que siga en paz la marcha de su historia sin quiebras ni rupturas, respetando la ley para todos y dejando constancia de la fidelidad al testamento de Franco y al juramento del rey" ${ }^{60}$

Por el tono del manifiesto, bien lo podría haber realizado un falangista «histórico» como era José Antonio Girón de Velasco, ya que las tendencias anticapitalistas de origen falangista mezcladas con el populismo franquista estaban más presentes que el lenguaje puramente reformista. Mas el contenido del manifiesto, así como su tonalidad, entroncaban fielmente con lo que querían representar las asociaciones firmantes (ANEPA, UDPE, UNE, FNE) en pleno 1976: el neofranquismo político. Pero ese discurso más anticapitalista de origen falangista sería el que iría desapareciendo y el que no sería tan común a nivel estatal, así como las referencias al 18 de Julio y al testamento de Franco, las cuales se irían substituyendo paulatinamente por conceptos populistas neofranquistas menos «movimentistas», pero sin que ello supusiera renegar de todo ello. Ese discurso más netamente «resistencialista de corte azul» se iría diluyendo- aunque sin desaparecer- en lo que sería la futura AP, entre otras cosas, porque la falangista

${ }^{60}$ AGA, Cultura, MIT. Gabinete de enlace, c.9152,Nota interior relativas a la Coordinadora de la Derecha Nacional, c.9152, "Manifiesto de la Coordinadora Montañesa de Fuerzas Nacionales», 6 de septiembre de 1976. 
FNE no entraría a formar parte de la plataforma aliancista, siendo substituida en las conversaciones iniciales para crear un "Frente Nacional» por la "centrista» RD de Manuel Fraga, la cual intentaría llevar el peso de AP. Aunque no hay que olvidar que el discurso "resistencialista» sería el más común en la inicial AP, especialmente por parte de UNE, ADE, seguidas de UDPE y USP (como escisión posterior de ANEPA), aunque no mediante un discurso de corte frontal y más «visceral» y ortodoxo como el desarrollado por la integrista FN y el conjunto de la extrema derecha neofranquista "guerracivilista", sino mediante el plasmado a través de un «reformismo continuista». En este sentido, aunque AP en su conjunto intentaría presentarse oficialmente como fuerza política englobada en el «centroderecha español», su origen, componentes y posicionamientos ideológicos (no hay que olvidar los posicionamientos mayoritarios de las bases y cuadros en contra de la Constitución de 1978), la delataban, mostrándola, como lo que realmente defendemos, a saber: una fuerza englobada en la extrema derecha nacionalpopulista postfascista y postindustrial de corte neofranquista.

Finalmente, del continuo de estas conversaciones entre las diferentes asociaciones surgiría a lo que sería AP a partir de octubre de 1976, aunque con la participación activa de Fraga y Silva Muñoz, los cuales, especialmente el primero, a partir de septiembre iniciaría una potencialización de la futura alianza. ${ }^{61}$ De las asociaciones que habían mantenido un constante diálogo desde que se iniciaron las reuniones dirigidas por Velo de Antelo, finalmente no cristalizaron su participación en AP, el FNE de Fernández-Cuesta ni el FI de Ramón Forcadell. En el caso de los falangistas, fue debido a la prioridad otorgada, por parte de FernándezCuesta, al pleito mantenido con el grupo de Márquez Horrillo por el nombre de FE-JONS y al intentó se reunir fuerzas, cara una posible unificación del disperso mundo falangista en una única agrupación. ${ }^{62}$ Por parte del FI, adoptó el nombre de Partido Social Regionalista (Unión Institucional) -PSR (UI)-, registrándose como asociación política a inicios de octubre de $1976,{ }^{63} \sin$ mayor repercusión para el atomizado mundo tradicionalista. Por su parte, en substitución de las dos citadas asociaciones, se integraría en las conservaciones el partido de Fraga, RD,

\footnotetext{
${ }^{61}$ "'Gran coalición", parece ser ya un hecho. Puede aparecer como Alianza Popular», ABC, 24 de septiembre de 1976. En el artículo se hace referencia a la reunión mantenida el día 23 de septiembre de 1976 entre Fraga, Silva, Fernández de la Mora, Martínez Esteruelas, López Rodó, López Bravo, Fernando Sordo y miembros de ANEPA. «Esta semana volverán a reunirse los cinco ex ministros de la "quíntuple alianza"”, La Vanguardia Española, 29 de septiembre de 1976. En esta ocasión se hace referencia a la reunión entre Fraga, Silva, López Rodó y Fernández de la Mora.

${ }^{62} \mathrm{R}$. Fernández-Cuesta: Testimonio, recuerdos y reflexiones, Dyrsa, Madrid, 1985, pp. 287-289.

${ }^{63}$ «El Ministerio de la Gobernación da a conocer las asociaciones políticas inscritas en el registro creado a tal efecto", La Vanguardia Española, 2 de octubre de 1976. Un breve seguimiento de los primeros pasos del PSR (UI), entre otros, en C. Ferrer González: «Los Carlismos de la Transición: las idiosincrasias carlistas frente al cambio político (1973-1979)", en J. C. Colomer, J. Esteve y M Domingo (coords.): Ayer y hoy. Debates, historiografía y didáctica de la historia, Publicacions de la Universitat de València,Valencia, 2015, pp. 151-155.
} 
el cual no había participado en las conservaciones iniciadas en 1974 para formar una gran coalición de fuerzas del 18 de Julio a través de un «Frente Nacional». El empuje de un Fraga excluido de los resortes institucionales oficiales franquistas tras su cese como ministro de la Gobernación en julio de 1976 por integrarse en las conversaciones, vino determinado por su deseo de influir en el debate en Cortes sobre la Ley para la Reforma Política (16, 17 y 18 de noviembre de 1976) mediante los procuradores adscritos a las asociaciones políticas fundadoras de la plataforma neofranquista aliancista. ${ }^{64} \mathrm{El}$ proceso culminaría como es harto conocido con la denominada «Gran Coalición de Derechas» llamada AP.

\section{COnCLusiones}

Como hemos citado anteriormente, en la formalización de AP confluyeron diversos factores determinantes, los cuales son clave a la hora de entender lo que significó AP. Por una parte la codificación de lo que sería AP, venía procesándose desde que las asociaciones más antiguas de la plataforma aliancista, UDPE, UNE y ANEPA junto a otras que finalmente no integraron AP, como el FNE de Fernández Cuesta o el FI del Ramón Forcadell, decidieran unir sus fuerzas en pro de la defensa de las esencias del 18 de Julio en un contexto en el que la incertidumbre sobre la evolución del régimen y supervivencia de éste parecía estar en peligro, entre otros, por las continuas movilizaciones sociales y la reorganización de la oposición democrática. Ese proyecto «resistencialista» franquista del que hemos hecho referencia, y del que Fraga inicialmente no tomó partido-primero tras ser vetado por Franco y posteriormente por fracasar la «Santa Alianza» (FragaAreilza-Silva) y segundo por asumir la cartera de gobernación durante el primer gobierno de la monarquía-, sería uno de los caminos que acabarían confluyendo en la constitución de AP.

Otro concepto sería, por qué Fraga finalmente constituye, en última instancia, la plataforma neofranquista de AP formando núcleo con gentes situadas a su extrema derecha y que poco tenían que ver el su proyecto reformista de GODSA y la imagen del Fraga «centrista» que tanto había hecho gala desde 1971. Ahora bien, que la inclusión de Fraga en el proyecto que acabaría siendo la plataforma

\footnotetext{
${ }^{64} \mathrm{El}$ papel de la naciente AP sería clave para la aprobación de la Ley para la Reforma Política con sus 183 procuradores (fuentes periodísticas del momento los cifraban, creemos que erróneamente, en 200 procuradores; M.A. del Río Morillas: De la extrema derecha..., cit., p. 86 -en especial nota 243 - y p. 367 -en especial nota 935-) y en la configuración del sistema electoral de las primeras y sucesivas elecciones legislativas como han remarcado, entre otros, F. Gallego (El mito de...cit.), C. Molinero y P.Ysàs (La anatomía del...cit.) o I. Sánchez-Cuenca (Atado y bien...cit.). Un seguimiento más profundo del papel de los procuradores adscritos a AP, en la aprobación de la Ley para la Reforma Política puede seguirse, en M.A. del Río Morillas: De la extrema...cit., pp. 339-399.
} 
neofranquista de AP produjera una crisis de identidad al proyecto "fraguista» de RD, y a todos aquellos que lo habían apoyado desde los «equipos» de Madrid y Barcelona, tampoco debe distorsionar la idea que Fraga y su RD y los otros miembros fundadores de AP eran incompatibles a modo de pacto contra natura. Todos ellos tenían en común la defensa de la legitimidad y legalidad franquista frente a aquellos que pregonaban la ruptura del régimen mediante un proceso constituyente (la oposición democrática). La diferencia entre las diversas tendencias dentro de AP era la metodología para frenar la ruptura, o bien mediante la reforma del régimen a través de sus estructuras y posibilidades jurídico-políticas (RD y Fraga) o bien mediante la apelación a la continuación «evolutiva-perfectiva» del régimen en su vertiente más continuista y ortodoxa de la doctrina histórica del 18 de Julio (la mayoría de las asociaciones que convergen en la plataforma y que remontan sus contactos en el marco asociativo del Movimiento Nacional que hemos visto, a saber: UDPE, UNE, ANEPA, por citar las más destacadas). Todas las tendencias de AP, en tanto en cuanto no querían romper con la legalidad vigente, entraban en la categoría de neofranquistas. Así, AP nacería como un proyecto de confluencia de diferentes proyectos reformistas franquistas, en su mayoría «resistencialistas», siendo la figura de Fraga la aglutinadora de todas ellas, a pesar de sus diferentes tendencias y sensibilidades neofranquistas. Por lo tanto, hablar de AP, es hablar de una macroasociación política que surge de asociaciones nacidas de las posibilidades legislativas de un régimen de extrema derecha, las cuales hacen suyas, como punto de origen, las legitimidades históricas derivadas del régimen del 18 de Julio. Por ende, partiendo de la base definitoria que el franquismo fue un régimen de extrema derecha, categorizar a las asociaciones nacidas del mismo como organizaciones de extrema derecha no debe de resultar contradictorio. ${ }^{65}$

Por otro lado, otro factor clave en la constitución de AP sería la exclusión de Fraga del segundo gobierno de la monarquía, así, como en un primer término,

\footnotetext{
${ }^{65}$ Según nuestro parecer, sin restar importancia a la presencia e influencia de miembros más «liberales» y «democráticos» en las filas de RD de Cataluña como Francisco Guillamón Vidal (excombatiente republicano encarcelado por su militancia socialista), Manuel Milián Mestre, Juan J. Folchi, Pedro Penalva, José M. Santacreu o Juan Echeverría, entre otros, o de planteamientos a favor del divorcio, la demanda de anticonceptivos gratuitos o a la asunción del aborto en cierto casos, así como la presencia de miembros a favor de la amnistía y la legalización de comunistas, no debe, a nuestro parecer, desvirtuar el carácter meramente anecdótico en el sí de la totalidad de RD (a excepción de personas como Félix Pastor Ridruejo, entre otros pocos) y plenamente residual en el sí de la plataforma aliancista, como puede seguirse en la constitución oficial de RD como partido en octubre de 1976 y en su primer congreso en diciembre de 1976 (véase M.A. del Río Morillas: De la extrema derecha..., cit., pp.280 y ss.). Estos sectores más «progresistas» convivían con sectores más ultras de RD como el representado por el «movimentista» valenciano Alberto Jarabo Payá (fundador de AP en Valencia, el cual votó negativamente a la Constitución). Ambos sectores, fieles a Fraga y a sus directrices, abogaban por la no ruptura con el régimen, lo cual creemos clave para determinar la naturaleza, con matices y no contradictoria, de los grupos y asociaciones integrantes en AP, entre ellos RD. Todo ello sería clave, a nuestro parecer, para su no homologación con una derecha liberal democrática nacida a partir del mito del antifascismo y de la ruptura con el fascismo/postfascismo
} 
del propio deseo del propio político gallego en interceder en el debate en Cortes sobre la aprobación de la Ley para la Reforma Política a través de los procuradores adscritos a las asociaciones políticas de AP. Por otra parte, no era imaginable, a la altura de inicios de 1976, que Fraga pudiera aliarse con personas que habían sido enemigos declarados, como López Rodó, o con personas que ideológicamente distaban mucho de su concepción reformista, como Fernández de la Mora, Silva Muñoz o Thomas de Carranza. Su salida del primer gobierno Suárez, junto la muestra de su faceta más autoritaria, así como la constitución de un partido desde el poder -UCD-, pudiera parecer que fuera repelido de su ansiado "centro", dejándole la única opción de situarse en el único espacio que quedaba «libre», eso era la derecha franquista y la extrema derecha. Su objetivo, con ello, sería intentar hacerse con el llamado "franquismo sociológico»-concepto este último que creemos necesario revisar y actualizar- constituido principalmente por clases medias que habían crecido en el «desarrollismo» franquista de los años sesenta, en los "XXV Años de Paz», en contraposición al franquismo más «político», que también podía votarles, pero que se anclaba en el franquismo "guerracivilista»e inicial de los años cuarenta y cincuenta y en el en franquismo de la "unificación", el cual sería defendido por Blas Piñar y FN, Girón de Velasco y la Confederación Nacional de Ex Combatientes o por Fernández-Cuesta y la Falange Española y de las JONS (FE-JONS). El sector «fraguista» de AP, con RD a la cabeza, se postuló por intentar cooptar el máximo de extrema derecha hacia la causa menos continuista que podía representar la figura de Fraga, en un intento de alejarla de la extrema derecha nostálgica a través de un discurso basado en poner el máximo de trabas al desarrollo de todo aquello que pudiera dinamitar la obra de Franco y su significado histórico como consecuencia de un «cambio» precipitado y $\sin$ control. Para ello, se explotaba la imagen del franquismo menos relacionado con la guerra civil, el miedo, el hambre o el aislamiento internacional, siendo el franquismo «desarrollista» de los años sesenta el contrapunto «evolucionista».

Por lo tanto, cualquier atisbo de definir a AP como un proyecto de derecha democrática a modo de movimientos conservadores europeos surgidos después del a II Guerra Mundial carece de toda lógica, siendo más coherente su comparación europea con movimiento de extrema derecha nacional-populista (MSI, NPD o FNa francés) insertos en el juego democrático -aunque originariamente anticonstitucionalistas, como en el caso de los orígenes del MSI- y partidarios de una democracia "fuerte/autoritaria» todos ellos, los cuales partían de la admiración y respeto a las experiencias fascistas aunque sin pretender proyectarlas hacia el futuro ni restaurarlas idénticamente como las correspondientes a la de los años

posterior a la II Guerra Mundialcomo la existente con matices en Alemania occidental, Francia o Italia. Por otro lado, diferentes interpretaciones la evolución ideológica de RD pueden seguirse, entre otros, en M. Penella: Los orígenes..., cit.; C. Palomares: Sobrevivir a..., cit.; J.B.: Culla: La dreta..., cit.; M. Milián Mestre: Els ponts..., cit.; M.A. del Río Morillas: «Los orígenes de AP..., cit. 
treinta y cuarenta. «Ni renegar ni restaurar» que diría el neofascista italiano líder del MSI G. Almirante. Asimismo, tampoco sería correcto definir a la inicial AP como un elemento englobado en la extrema derecha más ortodoxa o nostálgica como la representada por FN o la Confederación Nacional de Ex Combatientes que citábamos en el anterior párrafo, a pesar de que ambas a partían de la defensa de la legalidad vigente y de negativa a la apertura de un proceso constituyente. La diferencia entre ambas radicaba en qué franquismo se defendía y cuál de ellos se pretendía proyectar evolutivamente en el contexto político de 1977, a saber: el más fascista y "guerracivilista» de los años cuarenta y cincuenta o el franquismo «desarrollista» postfascista de los años sesenta y de los «XXV Años de Paz». Lógicamente ambas representaciones de la extrema derecha española, la neofranquista nacional-populista/evolutiva de AP y la neofranquista «resistencialista»/ortodoxa de FN, presentaban vasos comunicantes, y por lo tanto futuros votantes, como también los presentaban con votantes de UCD. Asimismo, al hilo de esta interpretación nos encontraríamos en posición de rebatir la teoría sobre la residual o testimonial presencia electoral de la extrema derecha durante la Transición española, ya que si adoptamos a AP como fuerza de extrema derecha nos encontraríamos que el peso electoral total de la extrema derecha española (la nacional-populista/ evolutiva y la ortodoxa) fue el más destacado de la Europa occidental de mediados y finales de los setenta. ${ }^{66}$

Finalmente, la propuesta de categorizar a AP, especialmente entre 1976 (fecha fundacional) y 1977/1979 (inicio debate constitucional / III Congreso Nacional de AP -aceptación obligada de la Constitución de 1978, salida de la FAP de los elementos más ultrafranquistas contrarios al texto constitucional, UNE y ADE, y tránsito hacia una derecha nacional, neoconservadora, democrática y postindustrial- $),{ }^{67}$ como una

\footnotetext{
${ }^{66}$ En caso del NPD alemán, en las elecciones generales de 1977, logró el 0’6\% del total de los votos, por su parte el FN francés obtuvo en las elecciones legislativas de 1978 un 0’29\% de los votos, mientras que el MSI italiano en 1976 obtuvo el 6’1\% de los votos emitidos; un seguimiento de los tres partidos, en F. Gallego: Neofascistas. Democracia y extrema derecha en Francia e Italia, Plaza \& Janés, Barcelona, 2004; íd.: De Auschwitz a Berlín. Alemania y la extrema derecha, 1945-2004, Plaza \& Janés, Barcelona, 2005. En las elecciones españolas de junio de 1977 la suma de votos de AP, Alianza Nacional 18 Julio -AN 18 de Julio- (coalición electoral formada por FN, Círculos Doctrinales José Antonio, Agrupación de Juventudes Tradicionalistas), FE-JONS (en algunas circunscripciones se presentó dentro de la AN 18 de Julio) y de otros grupúsculos falangistas dieron como resultado total una cifra superior al $8 \%$ de los votos emitidos; véase Ministerio del Interior (Dirección General de la Política Interior), Consulta de Resultados Electorales, Congreso / Junio 1977. Disponible on-line en: http://www.infoelectoral.mir.es/min/busquedaAvanzadaAction.html?vuelta=1EcodTipoEleccion $=2 E c o d$ Periodo $=197706 \&$ codEstado $=99 \& c o d$ Comunidad $=0$ EcodProvincia $=0$ EcodMunici pio $=0$ EcodDistrito $=0$ EcodSeccion $=0$ EcodMes $a=0$

${ }^{67} \mathrm{~J}$. Verstrynge: «El neo-conservadurismo, ideología de la sociedad post-industrial», en Alianza Popular: Alianza Popular. Conferencias (1981), Vicesecretaria de Relaciones Públicas y Publicidad, Madrid, s.f., pp.155-182 (intervención realizada en el Aula de Cultura de Alianza Popular, 4 de junio de 1981, Madrid). Asimismo, en el III Congreso Nacional de AP de diciembre de 1979 se definió oficialmente a la plataforma no como un movimiento de «derecha» o "centro-derecha», sino como
} 
fuerza de extrema derecha neofranquista y de reconocer que el principal partido vertebrador de la derecha española (el PP) surge de la extrema derecha (único en la experiencia europea de los movimientos conservadores democráticos), serían clave, según nuestro punto vista, para reflexionar sobre los dejes antidemocráticos que aún conserva la actual derecha española y que quedan reflejados, entre otros, en la negativa a aceptar una Ley de Memoria Histórica, en la dificultad a la hora de condenar el franquismo, en la asunción de un nacionalismo españolista conservador excluyente, en la concepción autoritaria de los usos de la política o en la mera defensa del orden y los valores tradicionales de la civilización cristiana. ${ }^{68}$

una opción "populista», «conservadora», «reformista», «democrática» y «liberal», a lo que habría que sumarle la categorización de «humanismo cristiano»como base filosófico-religiosa sobre la cual deberían pivotar todos esos términos (Alianza Popular: III Congreso Nacional. Ponencias, programa y estatutos, Alianza Popular, Madrid, 1980, pp. 29-33).

${ }^{68}$ Véase, también, un seguimiento de los valores de la actual derecha española desde la Transición, en C. Molinero y P.Ysàs: «Derechas e izquierdas en la España posfranquista», en M. Pérez Ledesma e I. Saz (coords.): Del franquismo a la democracia, 1936-2013, vol. IV, Marcial Pons / Prensas de la Universidad de Zaragoza, Zaragoza, 2015, pp. 365-379. 